\title{
From Paganism to Christianity and the Administrative-Ecclesiastical Integration of the Parishes on the Middle Valley of Târnava Mare in the Twelfth to Fourteenth Centuries
}

\author{
Adrian Nicolae Șovrea*
}

This paper aims at describing the process through which religious rites and rituals have changed within settlements located along the middle valley of the Târnava Mare River, evolving from pagan manifestations to the emergence of Catholic ecclesiastic institutions, contributing thus to a new regional religious identity. The archaeological findings of the Medias group indicates the practice of the cremation rite in this particular area, which was a common custom up until the mid-ninth century. In the following ninth to eleventh century period, however, there is a gap in archaeological evidence relevant to the funeral rite; no burial grounds or cemeteries have been identified, and only one settlement in Albesti (Mureș County) was found. The Târnava Mare basin was shortly encompassed within the Hungarian Kingdom. Thus, starting with the twelfth century, a series of indagines were built and defended by the Szeklers' communities. The cemetery on the so-called Dealul Viilor in Sighisoara is attributed to the Szeklers. A new burial ritual was observed, namely an anthropomorphic practice, after German populations settled down along the Târnava Mare valley and after the arrival of Dominican monks in Sighişoara, where they erected a Dominican convent. From an institutional point of view, these settlements were placed under the jurisdiction of the Transylvanian bishopric and of the chapters/ diaconates of Mediaș, Laslea/Criș, Târnava Mare, Târnava Mică, Saschiz, Tileagd.

Keywords: cremation, burial, Medias, group, Bijelo-Brdo group, Szeklers, settlers, deaneries, chapter (capitulum).

\section{Introduction}

The fall of the Roman Empire, the dissolution of its territories, and the subsequent rise of migratory waves and formation of power cores all around Europe, from West to East, marked what it is known as the Late Antiquity (third to seventh century) ${ }^{1}$ with its transition into the Early Middle Ages (sixth/seventh to tenth century). ${ }^{2}$ This was not just a simple shift of power.

\footnotetext{
* Șovrea Nicolae Adrian, Asistent în cercetare în arheologie, Universitatea „Lucian Blaga” Sibiu, Sighișoara, jud. Mureș, str. Gării, nr. 5, bl. 108,ap.7, sovrea_adrian@yahoo.com.

${ }^{1}$ Henri Irenee Marrou, Biserica în antichitatea târzie 303-604 (București: Universitas 1999).

2 Theodore E. Mommsen, "Petrarch's Conception of the "Dark Ages»," Speculum 17, 2 (1942): 226-27.
} 
If we factor in the process of Christianization, we come across a continental cultural change in the last decades of Antiquity and the first centuries of the Middle Ages. The fall was quick, but the rise of a new organic paradigm took centuries to come into place. Transylvania, as a former Roman province, with all that it entailed, from infrastructure to urban settlement, to trade and cultural exchange, was no exception from what followed between the last quarter of the fifth century and up until the tenth century. Territories had to be reclaimed, settlements had to be rebuilt, life itself had to continue and find new identities. For the people of those centuries, their religious identity was the most important aspect of their lives. With no established Christian tradition by the fall of the Empire, the region between the Carpathian arch was one of transition between paganism and Christianity. One of the best tools provided by modern-day research to help prove and observe this transition comes from the results of archaeological excavations. In the last three decades, after the fall of the communist regime, new schools of archaeology strived to move forward and to link the results of their work with those from Hungary and the Balkans. Transylvania has always found itself at the crossroad between two worlds, which for the Early Middle Ages meant Christianity and paganism. The archaeological findings, burial grounds or settlements have shown this mixture of faith for the period between the fifth to tenth century. It is through our following analysis of findings along the middle valley of Târnava Mare that we try to bring forward one micro-area in Transylvania which best reflects the phenomenon of biritualism, ${ }^{3}$ of paganism and Christianity visible in this micro-region. This emphasizes once again that this was an area where this change took time, and the limits of this change seen in the tenth century is given by the Hungarian conquest of this territory, which meant a new institutional authority that was capable to implement Christianity as a state religion, from the top to the bottom of society. In the centuries before, such authority lacked in Transylvania, including along the middle valley of the Târnava Mare River. Through archaeological discoveries, we can bring to light the existence of paganism in its biritual form, namely through an overview of this particular area, showing a phenomenon visible in present-day Hungary, Romania and Ukraine. Thus, we aim in bringing the reader's attention to the religious evolution along the middle valley of the Târnava Mare in a broader chronological framework and through a historical synthesis. Archaeological discoveries in this area have been the subject of several studies and therefore we will not dwell on the analysis of archaeological discoveries and historical documents. Instead,

\footnotetext{
${ }^{3}$ Biritualism refers to a burial place where two rites are visible: cremation and burial.
} 
we will only examine the particularity of this micro-region, where changes regarding the religious identity of its inhabitants occurred as a result of political factors, communities here undergoing thus cultural and spiritual transformations, provided they didn't altogether disappear or were replaced with other population.

The geographical limits of the Târnava Mică Valley are the watershed both from the south to the Hârtibaciu Valley and from the north to the Târnava Mică Valley, the Șoimuș and Saschiz valleys to the east, and to the west the Păucea and Moşnei valleys.

From the historic point of view, the emergence of the Magyar kingdom around the year 1000 brought a shift in power along the Middle Danube and in the Carpathian Basin. After defeating Gyula, the Hungarian king Stephen I had occupied Alba Iulia and western Transylvania. By the end of the eleventh century, his successors had managed to occupy the area between the Mureș and Târnava Mare rivers, advancing towards the Secaș high plains. ${ }^{4}$

The areas along the valleys of both Târnava rivers became part of the political and religious structure of the Hungarian kingdom during the twelfth and thirteenth centuries, while the defense of the southern Transylvanian borders was assigned to Germans, Romanians, Pechenegs (bisseni) and Szeklers. ${ }^{5}$

\section{Pagan rite and ritual along the Târnava Mare Valley during the ninth to eleventh centuries}

During the ninth century, the funeral rite and ritual in southern Transylvania reveals a transition from pagan rituals such as cremation and biritualism (Mediaș group) to inhumation (Blandiana B assemblage group) as a Christian manifestation.

The Mediaş, group (seventh to ninth century) was defined by the archaeologist Kurt Horedt, ${ }^{6}$ who named it after the archaeological site in Mediaș - Dealul Furcilor - and is characterized through the presence of both rites, cremation and inhumation. The practice of cremation in the Medias, group is visible in most of the burial grounds, while there have also been

\footnotetext{
${ }^{4}$ Ioan Marian Țiplic, "Contribuția pecenegilor, secuilor și sașilor la constituirea frontierei de sud a Transilvaniei (sec. XI-XIII)," Studia Universitatis Cibiniensis. Series Historia 1 (2004): 69-72.

${ }^{5}$ Maria Crîngaci T,iplic and Ioan Marian T,iplic, "Sudul Transilvaniei în secolul al XIII-lea, o graniță între spațiul catolic și spațiul non-catolic,” Revista Transilvania 10 (2016): 7-24.

${ }^{6}$ Kurt Horedt, "Die Brandgräberfelder der Mediașgruppe aus dem 7.-9. Jh. in Siebenbürgen," Zeitschrift für Archäologie (ZfA), 10 (1976): 39; I. M. Țiplic, "Necropolele de tip Mediaș din Transilvania," $A M N, 39-40,2$ (2002-2003): 9-22.
} 
some discoveries where only cremation has been used. ${ }^{7}$ Discoveries belonging to this group are to be found in Berghin, ${ }^{8}$ Boarta, ${ }^{9}$ Bratei, ${ }^{10}$ Ghirbom, ${ }^{11}$ Gușterița, ${ }^{12}$ Mediaș, ${ }^{13}$ Ocna Sibiului, ${ }^{14}$ Păuca, ${ }^{15}$ a.o. The Mediaș group is atypical for the ninth century, being chronologically placed between the seventh to ninth centuries, thus revealing the Slavic presence along the Târnava Mare Valley. This was a population that practiced cremation.

Archaeologically, the ninth century brings upon the end of the Mediaș group and the beginning of the cultural group known as Blandiana A. Furthermore, archaeologists were able to observe in south-western Transylvania a transition from the Slavic-Avar horizon to the Bulgarian one, as well as the presence of the Balkan-Danubian culture.

The archaeological finding has revealed the following cultural horizons for the ninth and tenth centuries: the Blandiana A group (the BalkanDanubian culture); the Ciumbrud group (Moravian culture); the Cluj group (early Magyar tribes).

Up until now, the archaeological map of the Transylvanian area shows rather a gap regarding the burial grounds along not only the Târnava Mare Valley during the ninth to tenth centuries, but also along the Hârtibaciu River and middle course of the Olt River.

The settlement in Albești, dated in the ninth to tenth century, is located within the middle basin of the Târnava Mare and describes a cultural and economic change. It is here where archaeologists have identified that most ceramic materials were made using the fast potter's wheel, resulting in different shapes of ceramic vessels. The clay these were made of contained

\footnotetext{
${ }^{7}$ George Tomegea, "Accesorii vestimentare și podoabe în necropolele birituale din Transilvania (sec. VII-IX)," Analele Banatului, 19 (2001): 209.

${ }^{8}$ Vasile Moga, Horia Ciugudean, Repertoriul arheologic al Județului Alba (Alba Iulia: Muzeul Naţional al Unirii, 1995), 56.

9 Sever Dumitrașcu and George Togan, "Cimitirul de la Boarta - «Pârâul Zăpozii - Șoivan»" Studii și Comunicări. Arheologie-istorie, 18 (1974): 93-108.

${ }^{10}$ Eugenia Zaharia, Populația românească în Transilvania în secolele VII-VIII (Cimitirul nr. 2 de la Bratei) (București: Editura Academiei Republicii Socialiste România, 1977).

${ }^{11}$ Ioan Al. Aldea, Eugen Stoicovici and Mihai Blăjan, "Cercetări arheologice în cimitirul prefeudal de la Ghirbom (comuna Berghin, jud. Alba)," Apulum, XVIII (1980): 151-177.

${ }^{12}$ Thomas Nägler, "Vorberich über die Untersuchungen im Hammersdorfer Gräberfeld aus der Völkerwanderungszeit", Forschungen zur Volks- und Landeskunde, 14 (Sibiu, 1971): 65.

${ }^{13}$ Horedt, „Die Brandgräberfelder,” 39.

${ }^{14}$ Dumitru Protase, Cimitirul slav de la Ocna Sibiului (sec. VIII-IX) (București-Sibiu: Editura Economică, 2005).

${ }^{15}$ I. M. T,iplic and George Tomegea, Păuca. Necropola de incinerație (secolele VIII-IX). Catalog de expoziție (Sibiu, 2016).
} 
a fine degreaser. The burning process took place at high temperatures and the vessels were equally burned on all sides, contrasting thus with the Slavic ceramic made by hand or with the slow potter's wheel, which resulted in simplistic products containing small pebbles, and were unevenly fired.

\section{The disappearance of paganism. Christianity and religious structures}

By occupying western Transylvania during the reign of Stephen I, the territory entered a specific phase of administrative-territorial development (counties) and an ecclesiastic one (bishopric and deaneries). The bishopric of Transylvania was established in this region of the kingdom around the year 1009, most likely with its seat, as Gyula Kristó says, in Cluj or its vicinity, and only later in Alba Iulia. ${ }^{16}$ It was Stephen I who also issued a series of laws regarding the ecclesiastic and religious structure, amongst which there was one stating that the old pagan burial grounds had to be abandoned and the Christian burial ground was supposed to be consecrated by a priest. ${ }^{17}$

According to Gyula Kristó, up until the reign of Ladislau I(1077-1095), the territory over which Stephen I's successors expanded their authority was north of the Mures, River, a territory including also their authority over the Transylvanian bishopric. This encompassed the counties of Solnoc, Dăbâca and Cluj. ${ }^{18}$ Furthermore, during that time, we are able to confirm the existence of Alba County.

The middle and upper courses of the Mureș River separated the Hungarian Kingdom from the other parts of Transylvania, which were controlled by Pechenegs settled outside the Carpathian arch. Starting with the reign of Ladislau I (1077-1095), territorial expansion became a policy of the kingdom and was continued under Coloman I (1095-1116) and his successors. The laws issued by Ladislau I and Coloman I stated that a burial ground was supposed to function around a church, the spiritual center of any community. ${ }^{19}$

The disruption of this practice was the result of the Pechenegs, ruled by Osul, being defeated in Chiraleș (near the fortress of Șirioara) by King Solomon (1063-1074) in 1068. King Ladislau then occupied the territories in the heart of Transylvania, expanding the indagines lines up until south of

\footnotetext{
${ }^{16}$ Gyula Kristó, Ardealul timpuriu (895-1324) (Szeged: Atelierul de Istorie Medievale, 2004), 119.

${ }^{17}$ Radu Harhoiu and Erwin Gáll, "Necropola din secolul XII de la Sighișoara-Dealul Viilor, punctul «Necropolă». Contribuții privind habitatul epocii medievale timpurii în Transilvania estică”, Analele Banatului 22 (2014): 207.

${ }^{18}$ Kristó, Ardealul, 131.

${ }^{19}$ Harhoiu and Gáll, "Necropola," 207.
} 
the Târnava Mare. ${ }^{20}$ The bishopric of Transylvania had reached across the Muress river course after $1080,{ }^{21}$ at the same time with the military and political Magyar administration. The Magyar penetration of the territory along the Târnava Mare Valley took place around the year $1100 .^{22}$

The reigns of Ladislau I and Coloman I are marked by two types of defenses: 1) indagines, a type of wood fortifications, and 2) a border guard that protected outlying settlements. The Szeklers and the Pechenegs were entrusted with border defense. Archaeological coin findings dating back to Ladislau I and Coloman I reveal the gradual occupation over the territories along the Someșul Mare, Târnava Mare and Hârtibaciu river courses. ${ }^{23}$

For their contribution, the Szeklers' gained political-military and social privileges. This acknowledgment of their military services contributed in shaping the medieval identity of the Szeklers, highly characterized by territoriality and autonomy. The medieval Szekler nation was born in the so-called „Szeklerland” (T,inutul Secuiesc) in south-east Transylvania in the eleventh century when the border guard role was defined and during the twelfth century after they received special privileges from the Hungarian kings that gave them heightened status. ${ }^{24}$

The expansion along the Târnava Mare valley marks a second phase in the movement of Szeklers (the first one being from the area of Bihor towards west and south of the Secașelor Plateau, namely the location of the Sebeș/ Sebus and Gârbova/Orbó deaneries) during the twelfth century. One of their most important communities settled down along the Târnava Mare Valley and a deanship was also established in Saschiz (Kézd). Thus, we suspect the existence of deanships in Sebeș and Gârbova in the time of the Szeklers. The Szeklers were eventually relocated in south-east Transylvania and the Orbó and Kézd communities shaped the future Orbai and Kézdi county seats in the Terra Siculorum. ${ }^{25}$

The so-called bisenii (magyarized Pechenegs) were also settled at the same time with the Szeklers. Their presence is proven by many place names in Transylvania, including some along the Târnava Mare Valley: in Stejăreni,

\footnotetext{
${ }^{20}$ I. M. T,iplic, “Contribuția,” 70-71.

${ }^{21}$ Kristó, Ardealul, 131.

${ }^{22}$ Nägler, Așezare sașilor în Transilvania și aportul lor la dezvoltarea societății feudale românești, in Studii de istorie a naționalității germane și a înfrățirii ei cu națiunea română, vol. 1 (București: Editura Politică, 1976), 17.

${ }^{23}$ Ana-Maria Velter, Transilvania în secolele V-XII. Interpretări istorico-politice și economice pe baza descoperirilor monetare din bazinul Carpatic, secolele V-XII (București: Paideia, 2002), $163-85$.

${ }^{24}$ Harhoiu and Gáll, "Necropola," 233-34.

${ }^{25}$ I. M. T,iplic, “Contribuția,” 70.
} 
formerly known as Beșeneu (Mureș County); in Boiu, a place name derived from the Pechenegs tribe of Baj (Mureș County), and possibly the settlement of T,opa (Mureș County). ${ }^{26}$

Regarding the religion and the rituals of the populations in the Târnava Mare valley after the eleventh century, we have the twelfth-century cemetery in Sighișoara - Dealul Viilor. This cemetery is a "cemetery surrounding a church" 27 , or another is that it is a "row” type ${ }^{28}$ with the church constructed nearby. Here were researched ninety-eight graves with one hundred and six individuals found. The individuals outnumber the graves as a result of burials within the same grave dated to different periods in time. The one hundred and six individuals were identified in the northern and southern areas of the cemetery, its central part not being investigated by archaeologists because the main road, linking Sighișoara with Boiu, crosses the cemetery through the middle. The unearthed graves consisted mostly of rectangular burial pits, three of them being however anthropomorphic ones (graves designed with a head niche; the burial pit was also dug according to the deceased's body shape). There lacks a rich funeral inventory, this being a feature of Christianity. In two cases „S-shaped head rings” were however discovered and in another six graves, archaeologists have found coins on the deceased with the function of oblation. ${ }^{29}$

The twelfth-century cemetery in Sighișoara - Dealul Viilor (The Hill of the Vineyards) brings testimony to the Szekler community in this region. The „S-shaped head rings" are typical for the second phase of Bijelo-Brdo cultural horizon (eleventh and twelfth centuries), being in daily use until the thirteenth century. One of the rings measures $4.2 \times 2.9 \mathrm{~cm}$, being one of the $\mathrm{S}$-shaped rings with the largest diameter, specific to the ones used during the twelfth century.

Archaeologically and chronologically, the material cultural aspects of the Bijelo-Brdo culture in Transylvania are detectable after the so-called Cluj group. The former consisted of two phases between the second half of the

\footnotetext{
${ }^{26}$ Adrian N. Șovrea, "Considerații asupra evoluției istorice a bazinului Târnavei Mari în secolele X-XIII din perspectivă toponimică și arheologică (II),” Alt-Schaessburg 13 (2020): 5-28; idem, "Grupuri de pecenegi pe valea mijlocie a Târnavei Mari", AMP 42 (2020): 31-42.

${ }^{27}$ Harhoiu and Gáll, "Necropola," 244-60.

${ }^{28}$ Crîngaci T,iplic, "Practica depunerii de monede în cimitirele din Transilvania (secolele XIXIII). Interpretări și perspective, Orbis Mediaevalis 1” (Arad 2017): 306-10.

${ }^{29}$ Harhoiu and Gáll, "Necropola", 244-60; Silviu Istrate Purece and Crîngaci T,iplic, "Prezența monedelor arpadiene în cimitirele din jurul bisericilor transilvănene," Transilvania 4 (2014): 19-28; Crîngaci Țiplic, "Practica," 301-23; Crîngaci Țiplic and Silviu I. Purece, "Biserici și cimitire medievale în lumina descoperirilor monetare (a doua jumătate a secolului al XI-lea/secolul al XIII-lea)," Transilvania 10 (2016): 33-53.
} 
tenth century and the twelfth. The graves that were typical for the early Magyar horizon - containing arches, arrows and harness elements - had disappeared during the first phase. During the second phase, the burials were characterized through a simpler ritual and the funeral inventory consisted of jewelry, including the S-shaped head rings. ${ }^{30}$ The Bijelo-Brdo culture is a multi-ethnic one, its material cultural elements being present within burials belonging to western Slavs, Hungarians and Szeklers. A possible explanation in this sense resides in the possibility of these groups belonging to the common population living within the Carpathian Basin (Pannonia and Transylvania). ${ }^{31}$

Thus, the laws issued during the reigns of Stephen I, Ladislau I and Coloman I had stated that Christian burials were to be undertaken within a Christian cemetery placed around a church and the Pagan ones abandoned. No offerings were allowed to be deposited inside the graves, but at the same time, there were representatives within communities who had the right to be buried closer to or even inside the church than others, thus revealing their social status. ${ }^{32}$

To the west of the cemetery is the settlement from Dealul Viilor that was mostly inhabited by Szeklers which were entrusted with military duties, shown also by two spurs found within the settlement and by wounds identified on the bodies of some deceased. However, the community also based its sustainability on growing cattle. The three anthropomorphic graves might indicate the presence of foreign ethnic elements living here, namely of German settlers. ${ }^{33}$ The members of this community were supposed to survey the Târnava Mare Canyon, which was closed to the west through a settlement. The royal stronghold of Segesvar was also nearby, on the place of the current Sighișoara stronghold, but there are divergent opinions on whether or not the former belonged to the community in Dealul Viilor. ${ }^{34}$

Another Szekler settlement was identified by archaeologists in BrateiNisipărie ${ }^{35}$ (Bratei - Gravel Pit). However, a specific burial ground has not been unearthed yet and the settlement expands over three to four generations.

\footnotetext{
${ }^{30}$ Aurel Dragotă, Aspecte de multiculturalitate spirituală. Rit și ritual funerar în Transilvania și Europa centrală și de sud-est (secolele IX-XI) (Alba Iulia: Editura Altip, 2006), 36-37.

${ }^{31}$ Alexandru Madgearu, Expansiunea maghiară în Transilvania (Târgoviște: Cetatea de Scaun, 2019), 72.

${ }^{32}$ Harhoiu and Gáll, "Necropola”, 244-60.

${ }^{33}$ Gheorghe Baltag, Sighişoara înainte de Sighişoara. elemente de demografie şi habitat în bazinul mijlociu al Târnavei Mari din preistorie până în sec. al XIII-lea d. Hr., cu privire specială asupra zonei municipiului Sighişoara (București: Oscar Print, 2000), 201-202.

${ }^{34}$ Idem, Sighişoara-Schässburg-Segesvár, (Cluj-Napoca: Nereamia Napocae, 2004), 24; Harhoiu and Gáll, "Necropola", 244-60.

${ }^{35}$ Adrian Ioniță, Așezarea din secolele XII-XIII de la Bratei, (Alba Iulia: Editura Altip, 2009).
} 
The settlement from Albești - La Cetățea (At the Fortress) has one of its layers dated back to the eleventh and twelfth centuries, ${ }^{36}$ while a fortification dated later in the thirteenth and fourteenth centuries contained a small-sized church or chapel ${ }^{37}$ at Cetătuia (The Fortress) (both sites are located along the Șapartoc Valley, circa five km south-east of Dealul Viilor).

The German settlements in southern Transylvania began during the reign of Géza II (1141-1162) and the western ritual, typical to the German world, had thus entered the region as well through the emergence and spread of anthropomorphic graves. ${ }^{38}$ However, these were not necessarily defining the German settlers' ritual, the burials with or without a casket having been also unearthed by archaeologists.

The anthropomorphic graves are characterized by shaping the burial pit according to the deceased body shape, by emphasizing the head shape through a skull niche. These niches were either rectangular, trapeze-shaped or circular, visible in both graves of higher-ranked clergy- or laymen or in those of common people. ${ }^{39}$ Other types of anthropomorphic graves were those designed with a stone or brick cist, but these were rather visible within monastic, clergy or nobility burials. ${ }^{40}$ In Transylvania, these kinds of graves are dated back to the twelfth and thirteenth centuries and show the presence of German settlers. ${ }^{41}$

Anthropomorphic graves dating to the twelfth to thirteenth centuries were identified by archaeologists along the Târnava Mare valley in Mediaș - Lutheran parish church (it was here that twelfth century graves were researched containing head rings with an S-shaped ending belonging to the Bijelo-Brdo cultural horizon, but also thirteenth-century anthropomorphic

\footnotetext{
${ }^{36}$ Baltag, Sighișoara înainte de Sighișoara, 203-15.

${ }^{37}$ Ibidem, 217; Adrian Andrei Rusu, "Două biserici arheologice din județul Mureș. Analize și interpretări”, Arhitectura religioasă medievală din Transilvania 5 (Satu Mare 2012): 112-15.

${ }^{38}$ Ioniță, "Mormintele cu gropi antropomorfe din Transilvania și relația lor cu primul val de colonizare germană", in Relații interetnice in Transilvania (secolele VI-XIII), eds. Zeno Karl Pinter, I. M. Țiplic and Crîngaci Țiplic (București: Editura Economica, 2005), 217-28; Daniela Marcu Istrate and Angel Istrate, "Morminte cu nișă cefalică descoperite la Alba-Iulia (sec. XII-XIII). Contribuții privind istoria oaspeților occidentali în Transilvania”, in Relații interetnice, eds. Pinter, I. M. Țiplic and Crîngaci T,iplic, 229-244; Crîngaci TTiplic, „Oaspeți germani” în sudul Transilvaniei. Istorie, arheologie și arhitectură (secolele XII-XIII) (București: Editura Academiei Române, 2011), 121-35.

${ }^{39}$ Ioniță, "Mormintele”, 215.

${ }^{40}$ Marcu Istrate and A. Istrate, "Morminte cu nișă cefalică", 229-44; Marcu Istrate, "Anthropomorphic tombs built of brick in the medieval cemetery of Sibiu", Banatica 23 (2013): 371-91; Harhoiu and Gáll, "Necropola", 224-26.
}

${ }^{41}$ Ioniță, "Mormintele", 215. 
graves) ${ }^{42}$ Moșna - Lutheran church, ${ }^{43}$ Sighișoara - Dealul Viilor, Sighișoara - Monastery church, ${ }^{44}$ Sighișoara - Church in the Hill. ${ }^{45}$

In southern Transylvania, anthropomorphic graves were also found in Alba Iulia - catholic church, Drăușeni - fortified church. ${ }^{46}$ Feldioara Lutheran church, Orăștie - Stronghold, Sibiu - Huet Square, Viscri - the cemetery around the church.

During the thirteenth century, the use of anthropomorphic graves came to an end. The deceased were now being wrapped in a shroud, or put to rest inside a casket placed in a rectangular pit. This became the prevalent way of burial. ${ }^{47}$

\section{The administrative and ecclesiastic structure along the Târnava Mare valley between the thirteenth to fourteenth centuries}

The Transylvanian bishopric was structured into thirteen arch deaneries spreading across its entire territory, but also reaching the one beyond the Meses, Gates, namely Ugocea and Satu Mare, while the Crasna arch-deaconry reached the area west and east of the Meseș Gates as well. Thus, ten arch-deaneries were left for the Transylvanian territory: Solnoc, Dăbâca, Cluj, Ozd, Turda, Alba, Hunedoara, Târnava, Tileagd, Chizd. ${ }^{48}$ The provostship of Sibiu was also functioning in Transylvanian independent of the bishopric and placed under the authority of the Archbishopric in Strigoniu, just like the land of Făgăraș.

The middle Târnava Mare Valley, as it was depicted in the Introduction, encompassed settlements belonging to the counties of Alba, Târnava, Două Scaune/ Zwei Stühle (Mediaș and Șeica Mare), the seat of Sighișoara and the one of Odorhei. Ecclesiastically, these were under the jurisdiction of the arch deaneries of Alba, Târnava and Tileag, all part of the Transylvanian bishopric.

The archdeaconry of Alba was divided into eight deaneries: Orăștie, Sebeș, Șpring, Saschiz, Coșdu, Criș, Mediaș, Șeica. The archdeaconry of Târnava

\footnotetext{
${ }^{42}$ Repertoriu Arheologic al județului Sibiu (2003), 134.

${ }^{43}$ RepArhSibiu, 145; Daniela Marcu, Cosmin C. Rusu, Szöcs Péter, Iosefina Postăvaru and Adriana Câmpean, "Moşna, com. Moşna, jud. Sibiu, Punct: Biserica evanghelică şi cetatea ţărănească. Cod sit: 145113.03”, CCA (2000): 60.

${ }^{44}$ A. Istrate, "Sighişoara, jud. Mureş. Punct: Cetate, Biserica Mănăstiri”, CCA (2006): 328.

${ }^{45}$ Daniela Marcu, Ioan F. Pascu, "Sighişoara, jud. Mureş. Punct: Biserica din Deal”, CCA (2000).

${ }^{46}$ Marcu, "Șantierul arheologic de la Drăușeni”, Buletinul Comisiei Monumentelor Istorice 5, no. 1-4 (1994): 19-25; idem, "Biserica fortificată de la Drăușeni, jud. Brașov", Arhitectura religioasă medieval din Transilvania 2 (Satu Mare, 2002): 41-78.

${ }^{47}$ Ioniță, "Mormintele", 215.

${ }^{48}$ Documente privind Istoria Românilor veacul IV. C. Transilvania (1953, 1), 122-253.
} 
(not to be interpreted as the Trnava archdeaconry in the Györ bishopric) was structured into the deaneries of Târnava Mare and Târnava Mică. German parishes belonging to the deaneries of Saschiz, Criș, Mediaș, Șeica, Băgaciu and Bălcaciu were also functioning within the middle Târnava Mare Valley.

The provostship in Sibiu did not have any authority over the German settlements located along the Târnava Mare Valley, so the deaneries located on county territory did not benefit from the privileges stipulated by the libertas Cibiniensis and thus were placed under the authority of the Transylvanian bishopric.

The emergence of a German settlement along the Târnava Mare Valley took place in the mid-thirteenth century when they were settled in the seats of Mediaș, Șeica and Sighișoara. In the area between the two Târnava rivers, this had happened by the end of the same century and the beginning of the fourteenth, marking one last phase in the German settlement upon county territory (which belonged to the nobility). Thus, the privileges received here by the settlers were different from the ones received by the ones living on the royal lands.

Furthermore, the question arises whether an archdeaconry had even existed along the Târnava Mare Valley by 1199, or even during the twelfth century. The Hungarian historian Gyula Kristó ${ }^{49}$ was inclined to agree upon its functioning around the year 1199, with a dean in Saschiz (Kézd), based on this document: „Hilario Archidiacono de Quiz. Cum a nobis petitur quod justum est, etc, archidiaconatum de Quiz cum omnibus pertinentiis suis, sicut ipsum juste possides et quiete, etc, ut supra, Nulli ergo, etc." ${ }^{50}$ The document refers to Pope Ince (Innocent) appointing Hylarius of Quizd (Kézd) as archdean of Kézdi by the latter's own request.

The document is slightly vague and does not prove to refer to an archdeacon along the Târnava Mare valley. We will not go any further with the issue of the archdeacon of Chizd (Kézd). However, if this was located along the Târnava Mare valley by 1199 , then the burial ground in Sighișoara Dealul Viilor and the second settlement in Bratei as those from Albești - La Cetățea, attributed to Szekler population, would have been under the jurisdiction of this ecclesiastic structure. It was only by 1277 that the archdeacon of Târnava was mentioned in documents, and the ones of Târnava Mare and Târnava Mică, by 1309 .

A document issued in 1309 proves the activity of the Saschiz deanery with its deanery seat in the same settlement, with a catholic dean (provost).

\footnotetext{
${ }^{49}$ Kristó, Ardealul, 131.

${ }^{50}$ Jakó Zsigmond, "Erdélyi okmánytár I. (1023-1300)”, Magyar Országos Levéltár kiadványai, II. Forráskiadványok 26 (1997): 130; Jacques-Paul Migne, PL (1800), 809.
} 
The document dated back to 1309 proves the existence of the Saschiz deanery, with its seat in the namesake settlement. A dean resided there as well. By the mid-sixteenth century, Saschiz became a Lutheran chapter. ${ }^{51}$ The parishes Apold, Daia, Netuș, Saschiz, Sighișoara, Șaeș belonged to this deanery, as well as others, as it was stated in later documents from the sixteenth and seventeenth centuries (after the Reformation): Archita, Beia, Brădeni, Bunești, Cloașterf, Criț, Drăușeni, Fișer, Jimbor, Meșendorf, Roadeș, Vulcan. ${ }^{52}$ According to Thomas Nägler ${ }^{53}$ these were followed by Albești, Vânători, Zoltan (Mihai Viteazu) and to Mariana Borcoman, ${ }^{54}$ Daneș and Văleni.

The deanery of Criș, later Laslea, ruled over Mălâncrav, Criș, Beșa (Stejărenii), Felța (Florești), Nou Săsesc, Roandola. In the fourteenth century, the deaneries' seat was Criş, as it was stipulated in a document dated to 1309, which records a trial between deaneries Sebeș, S,pring, Saschiz, Coșdu, Criș, archdeaconry Târnava Mare and archdeaconry Târnava Mică against the Transylvanian bishop. ${ }^{55}$

The deanery of Mediaș was first mentioned in 1283 in relation to a trial against the chapter of Alba. The priests of eight settlements within the chapter were thus mentioned: Walter the dean in Ațel, Ioan from Biertan, Henric from Richiș, Petru from Moșna, Adam from Mediaș, Siffrid from Brateiu, Henric from Șaroș and Teodor from Copșa Mare. ${ }^{56}$

The archdeaconry of Târnava, documented in $1277,{ }^{57}$ spread mostly along the Târnava Mică River Valley but also had under its jurisdiction some parishes placed along the Târnava Mare River. Later, two archdeaconries were in function and documented by 1309: the one of Târnava Mare and the one of Târnava Mică. Of all these, the Târnava Mare archdeaconry had under its jurisdiction parishes located along the middle valley of the Târnava Mare River.

During the fourteenth century, the Târnava Mare archdeaconry comprised under its jurisdiction the parishes of Curciu, Dârlos, Ebeșfalva (Dumbrăveni) and Hoghilag. ${ }^{58}$ After the Reformation, other parishes have

${ }^{51}$ Liviu Cîmpeanu, "Saschizul în Evul Mediu”, in Monografia localității Saschiz, ed. Florentina Călugăr (Târgu-Mureș: Nico, 2011).

${ }^{52}$ Ibidem.

${ }^{53}$ Nägler, Așezarea sașilor în Transilvania (București: Kriterion, 1992), 222.

${ }^{54}$ Mariana Borcoman, Sighişoara și așezările Scaunului omonim (Cluj-Napoca: Argonaut, 2020), 25.

${ }_{55}$ Documente privind Istoria Românilor veacul IV. C. Transilvania (1953, 1), 104.

${ }^{56}$ Documente privind Istoria Românilor veacul XIII. C. Transilvania (1952, 2), 249-50.

${ }^{57}$ Ibidem, 187.

${ }^{58}$ Documente privind Istoria Românilor veacul XIV. C. Transilvania (1954, 3), 131-32 and 144-45. 
been documented, namely the ones of Alma, Boiu, Giacăș, Hetiur, Prod, Seleuș, Șmig.

The archdeaconry of Tileagd ruled over most parishes in the Szekler land and, at one point, it also had jurisdiction over the parish of Hejjasfalva (Vânători), Eliseni, Șoard and Șoimușu Mare. ${ }^{59}$ These parishes, located along the middle valley of the Târnava Mare River, were under the Erdeuhath (Pădureni) conscription, belonging thus to the Tileagd archdeaconry.

The medieval documents also mention a series of properties along the Târnava Mare Valley that belonged to the Benedictine abbey in ClujMănăștur, one of the earliest order's establishments in Transylvania. ${ }^{60}$ After the Mongol invasion of 1241-1242, the provostship in Sibiu, the deanery of the so-called Burzenland and the Benedictine abbey in Cluj-Mănăștur were placed under the jurisdiction of the archbishopric in Strigoniu. ${ }^{61}$ In 1348, the abbey in Cluj-Mănăștur was in possession of several villages along the Târnava Mare: Seleuș, Hoghilag, Prod, Laslea. ${ }^{62}$ These were also mentioned as such in a document issued in $1411 .^{63}$

\section{Conclusions}

Between the ninth and fourteenth centuries, the religious rite and ritual along the middle valley of the Târnava Mare revealed pagan manifestations. However, the emergence of institutional Christianity and the development of Catholic institutions in this area began in the twelfth century.

The pagan-Christian contrast is best represented by the Mediaș archaeological group, revealing the use of cremation and of biritualism until the mid-ninth century. The following period of the ninth to eleventh centuries was marked by an archaeological gap, without any findings of burial grounds or cemeteries, only that of the settlement in Albești (Mureș County), which has been dated to this timeline. The Christian ideology was brought into this valley by the institutionalized Church.

During several stages, starting with the twelfth century and up until the second half of the thirteenth, which coincides also with the control over the Burzenland, Transylvania became part of the Hungarian Kingdom and

\footnotetext{
59 Ibidem, 200; Györffy György, Az Áppád-kori Magyarország történeti földrajza, (Budapest: Akadémiai Kiadó, 1987), 197.

${ }^{60}$ Corina Hopârtean, "Apariția ordinelor monastice catolice în regatul Ungariei și în Transilvania în secolele XI-XII", Anuarul Institutului de Cercetări Socio-Umane Sibiu 16 (2019): 55-57.

${ }^{61}$ Crîngaci T,iplic, "Prepozitura," 49.

${ }^{62}$ Urkundenbuch zur Geschichte der Deutschen in Siebenbürgen 2 (1892): 56.

${ }^{63}$ Urkundenbuch 3 (1892): 513.
} 
Christianity became the dominant rite and ritual. Due to the laws issued by kings Stephen I, Ladislau I and Coloman I, Christian communities were compelled to develop cemeteries without any kind of pagan elements and be located around a church. Up until then, row cemeteries located in the vicinity of a church were in use. Furthermore, not all churches were made of stone, some were built out of wood. This was the case mostly within Szekler settlements, which oftentimes were relocated within the kingdom, as its territory expanded. That was due to their obligation to defend the kingdom's borders, the Szeklers being its border guards. However, the number of stonebuilt churches in Szekler communities located in eastern and south-eastern Transylvania grew in numbers.

Consequently, after the occupation of the Târnava Mare Valley around the year 1100, in the area of its middle course, archaeologists have identified the cemetery in Dealul Viilor (Sighișoara) and attributed it to the Szekler population. While no cemeteries were unearthed, settlements have been found in Bratei-Nisipărie and Albești-La Cetățea. The typical Christian ritual is poor in funeral inventory and of Catholic influence. The archaeological research within the cemetery in Dealul Viilor was not successful in identifying the church's location. There have been only theories, which placed the cemetery around a church. The church might have been in the middle of the cemetery, an area that was not researched, or the cemetery might have been a row type one with the church in its vicinity. Three anthropomorphic graves were found in Dealul Viilor, revealing the presence of multiple ethnicities. This type of burial was typical of the German population or members of monastic orders or ruling elite. The findings of typical Bijelo-Brdo " $S$ "-shaped head rings testify to the presence of Szekler communities. The rings were linked to the horse spurs found in the settlement three hundred and fifty meters west from the cemetery at the archaeological site named Asezare (Settlement).

Around the year 1200, once German settlers arrived along the Târnava Mare River Valley, the anthropomorphic burials indicate a new ritual. Not all colonists used this burial. These were found in several locations in the region: Mediaș, Sighișoara, Moșna, as well as within churches built by the same population. The churches that were initially built by the German settlers were wooden ones, but shortly, if not immediately after they settled, they began erecting mostly Romanesque stone ecclesiastic.

Institutionally, the communities entered the jurisdiction of the Transylvanian Catholic bishopric and the deaneries of Mediaș, Criș, Târnava Mare, Târnava Mică, Saschiz, Tileagd.

In the valley of Târnava Mare, we notice a transition from paganism to Christianity through politics. Communities are undergoing major 
Adrian Nicolae Șovrea

changes, even among the population. For example, Szekler villages are abandoned by them under the orders of the king and replaced by German settlers. Therefore, paganism was rooted in political imposition and not in the choice of the community level.

\begin{tabular}{|c|c|c|c|c|c|c|}
\hline No. & $\begin{array}{l}\text { Settle- } \\
\text { ment }\end{array}$ & $\begin{array}{l}\text { Hungarian } \\
\text { / German } \\
\text { settlement } \\
\text { name }\end{array}$ & $\begin{array}{l}\text { The first } \\
\text { documented } \\
\text { mention }\end{array}$ & $\begin{array}{l}\text { Ecclesiastic } \\
\text { structure } \\
\text { (deanery) }\end{array}$ & $\begin{array}{l}\text { Administra- } \\
\text { tive struc- } \\
\text { ture (seat / } \\
\text { county) }\end{array}$ & $\begin{array}{l}\text { The first } \\
\text { documented } \\
\text { mention } \\
\text { showing the } \\
\text { administra- } \\
\text { tive unit }\end{array}$ \\
\hline \multicolumn{7}{|c|}{ South of the Târnava Mare River } \\
\hline 2. & Albești & $\begin{array}{l}\text { Fehéregyház/ } \\
\text { Weißkirich }\end{array}$ & 1231 & $?$ & Alba & $1810 / 1811$ \\
\hline 3. & Apold & $\begin{array}{l}\text { Trapóld/ } \\
\text { Trappold }\end{array}$ & 1231 & Saschiz & Sighișoara & 1309 \\
\hline 4. & Ațel & Hetzeldorf & 1283 & Mediaș & \begin{tabular}{|l} 
Două \\
Scaune
\end{tabular} & 1283 \\
\hline 5. & Biertan & \begin{tabular}{|l|} 
Berethalom/ \\
Birthälm
\end{tabular} & 1283 & Mediaș & $\begin{array}{l}\text { Două } \\
\text { Scaune }\end{array}$ & 1283 \\
\hline 6. & Brateiu & \begin{tabular}{|l} 
Pretai/ \\
Baráthely
\end{tabular} & 1283 & Mediaș & $\begin{array}{l}\text { Două } \\
\text { Scaune }\end{array}$ & 1283 \\
\hline 7. & Buzd & Buzd/ Buss & 1334 & Mediaș & $\begin{array}{l}\text { Două } \\
\text { Scaune }\end{array}$ & 1334 \\
\hline 8. & $\begin{array}{l}\text { Copșa } \\
\text { Mare }\end{array}$ & $\begin{array}{l}\text { Nagykapus/ } \\
\text { Griszkopesch }\end{array}$ & 1283 & Mediaş & $\begin{array}{l}\text { Două } \\
\text { Scaune }\end{array}$ & 1283 \\
\hline 9. & Criș & $\begin{array}{l}\text { Keresd/ } \\
\text { Kreisch }\end{array}$ & 1305 & Criș & Alba & 1309 \\
\hline 10. & Daia & \begin{tabular}{|l|} 
Szász-Dálya/ \\
Dändref
\end{tabular} & 1280 & Saschiz & Sighișoara & 1766 \\
\hline 11. & Daneș & \begin{tabular}{|l|} 
Dános/ \\
Dunnesderf
\end{tabular} & 1348 & Criș & Sighișoara & 1532 \\
\hline 12. & Dupuș & \begin{tabular}{|l|} 
Tobiás/ \\
Tobsdorf
\end{tabular} & 1286 & Mediaș & \begin{tabular}{|l|} 
Două \\
Scaune
\end{tabular} & 1334 \\
\hline 13. & Florești & \begin{tabular}{|l|} 
Felța/ \\
Fälzenderf
\end{tabular} & 1305 & Criș & Alba & 1532 \\
\hline 14. & Laslea & $\begin{array}{l}\text { Szt. László/ } \\
\text { Groß-Lasseln }\end{array}$ & 1309 & Criș & Sighișoara & 1309 \\
\hline 15. & Mălâncrav & $\begin{array}{l}\text { Almakerék/ } \\
\text { Malmkrog }\end{array}$ & 1305 & Criș & Alba & 1309 \\
\hline
\end{tabular}


From Paganism to Christianity

\begin{tabular}{|c|c|c|c|c|c|c|}
\hline 16. & $\begin{array}{l}\text { Nou } \\
\text { Săsesc }\end{array}$ & \begin{tabular}{|l} 
Apaújfalau/ \\
Sächs \\
Neudorf
\end{tabular} & 1305 & Criș & Sibiu & 1532 \\
\hline 17. & Richiș & $\begin{array}{l}\text { Riomfalva/ } \\
\text { Reichesdorf }\end{array}$ & 1283 & Mediaș & Alba & 1283 \\
\hline 18. & Roandola & \begin{tabular}{|l|} 
Rudály/ \\
Raunthal
\end{tabular} & 1322 & Criș & Alba & 1532 \\
\hline 19. & Saschiz & \begin{tabular}{|l}
$\begin{array}{l}\text { Szászkézd/ } \\
\text { Keisd }\end{array}$ \\
\end{tabular} & 1309 & Saschiz & Sighișoara & 1309 \\
\hline 20. & Sighișoara & $\begin{array}{l}\begin{array}{l}\text { Segesvár/ } \\
\text { Schäßburg }\end{array} \\
\end{array}$ & 1280 & Saschiz & Sighișoara & 1309 \\
\hline 21. & Stejăreni & Beșa/ Besse & 1305 & Criș & Alba & 1532 \\
\hline 22. & Şaeș & $\begin{array}{l}\text { Segesd/ } \\
\text { Schaas }\end{array}$ & 1302 & Saschiz & Sighișoara & 1309 \\
\hline 23. & Şaroș & \begin{tabular}{|l} 
Szászsáros/ \\
Scharosch
\end{tabular} & 1283 & Mediaș & \begin{tabular}{|l} 
Două \\
Scaune
\end{tabular} & 1283 \\
\hline 24. & Șapartoc & $\begin{array}{l}\text { Sárpatak/ } \\
\text { Schorpen- } \\
\text { dorf }\end{array}$ & 1231 & $?$ & Alba & $1810 / 1811$ \\
\hline 25. & Valchid & \begin{tabular}{|l|} 
Válthid/ \\
Waldhütten \\
\end{tabular} & 1317 & Mediaș & \begin{tabular}{|l} 
Două \\
Scaune
\end{tabular} & 1334 \\
\hline 26. & Vânători & \begin{tabular}{|l|} 
Héjásfalva/ \\
Teufelsdorf
\end{tabular} & 1297 & Erdeuhath & Tileagd & 1332 \\
\hline 27. & Vulcan & $\begin{array}{l}\text { Volkány/ } \\
\text { Wolkendorf }\end{array}$ & 1315 & $?$ & Sighișoara & 1592 \\
\hline
\end{tabular}

Fig. 1. Ecclesiastic and administrative-political parish structures south of the Târnava Mare River

\begin{tabular}{|l|l|l|l|l|l|l|}
\hline No. & $\begin{array}{l}\text { Settle- } \\
\text { ment } \\
\text { ian / German } \\
\text { settlement } \\
\text { name }\end{array}$ & $\begin{array}{l}\text { Hungar- } \\
\text { The first } \\
\text { mention }\end{array}$ & $\begin{array}{l}\text { Ecclesias- } \\
\text { tic struc- } \\
\text { ture- } \\
\text { deanery }\end{array}$ & $\begin{array}{l}\text { Administra- } \\
\text { tive structure }\end{array}$ & $\begin{array}{l}\text { The first } \\
\text { documented } \\
\text { mention } \\
\text { showing the } \\
\text { ecclesiastic } \\
\text { unit }\end{array}$ \\
\hline \multicolumn{7}{|c|}{ North of the Târnava Mare River } \\
\hline 1. & Alma & $\begin{array}{l}\text { Küküllőalmás/ } \\
\text { Almaschken }\end{array}$ & 1317 & T. Mare & Târnava & 1586 \\
\hline 2. & Boiu & Felső-Bun & 1301 & T. Mare & Târnava & 1586 \\
\hline 3. & Curciu & Körös/ Kirtsch & 1322 & T. Mare & Târnava & 1332 \\
\hline 4. & Dârlos & Darlóc/ Durles & 1317 & T. Mare & Târnava & 1332 \\
\hline
\end{tabular}


Adrian Nicolae Șovrea

\begin{tabular}{|c|c|c|c|c|c|c|}
\hline 5. & $\begin{array}{l}\text { Dumbră- } \\
\text { veni }\end{array}$ & $\begin{array}{l}\text { Erszebétváros/ } \\
\text { Elisabethstadt }\end{array}$ & 1332 & T. Mare & Târnava & 1332 \\
\hline 6. & Eliseni & $\begin{array}{l}\text { Székelyszen- } \\
\text { terzsébet }\end{array}$ & 1333 & $\begin{array}{l}\text { Erdeu- } \\
\text { hath }\end{array}$ & Odorhei & 1333 \\
\hline 7. & Ernea & $\begin{array}{l}\text { Szászernye/ } \\
\text { Ehrgang }\end{array}$ & 1339 & $?$ & Târnava & ? \\
\hline 8. & Giacăș & $\begin{array}{l}\text { Gyákos/ Goge- } \\
\text { schdorf }\end{array}$ & 1337 & T. Mare & Târnava & 1722 \\
\hline 9. & Hetiur & $\begin{array}{l}\text { Hétur/ } \\
\text { Marienburg }\end{array}$ & 1301 & T. Mare & Târnava & 1722 \\
\hline 10. & Hoghilag & $\begin{array}{l}\text { Holdvilág/ } \\
\text { Halwelagen }\end{array}$ & 1332 & T. Mare & Sighișoara & 1332 \\
\hline 11. & Păucea & $\begin{array}{l}\text { Pócstelke/ } \\
\text { Puschendorf }\end{array}$ & 1366 & $?$ & Târnava & $?$ \\
\hline 12. & Prod & $\begin{array}{l}\text { Pród }(\mathrm{t}) / \\
\text { Pruden }\end{array}$ & 1348 & T. Mare & Sighișoara & 1722 \\
\hline 13. & Săcel & $\begin{array}{l}\text { Székelyandrás- } \\
\text { falva }\end{array}$ & 1373 & ? & Odorhei & ? \\
\hline 14. & Seleuș & $\begin{array}{l}\text { Nagyszölös/ } \\
\text { Gross-Alisch }\end{array}$ & 1348 & T. Mare & Sighișoara & 1722 \\
\hline 15. & Șmig & $\begin{array}{l}\text { Somogyon/ } \\
\text { Schmiegen }\end{array}$ & 1317 & T. Mare & Târnava & 1722 \\
\hline 16. & Şoard & Sárd/ Sárd & 1301 & $\begin{array}{l}\text { Erdeu- } \\
\text { hath }\end{array}$ & Târnava & 1333 \\
\hline 17. & $\begin{array}{l}\text { Șoimuşu } \\
\text { Mare }\end{array}$ & Nagysolymos & 1333 & $\begin{array}{l}\text { Erdeu- } \\
\text { hath }\end{array}$ & Odorhei & 1333 \\
\hline 18. & $\begin{array}{l}\text { Șoimuşu } \\
\text { Mic }\end{array}$ & Kissolymos & 1566 & - & Odorhei & - \\
\hline 19. & Țopa & Csopofalva & 1672 & - & Târnava & - \\
\hline 20. & Uilac & Újlak & 1301 & $?$ & Târnava & $?$ \\
\hline 21. & Vidacut & $\begin{array}{l}\text { Oláhhidegkut } \\
\text { și Magyarhide- } \\
\text { gkút }\end{array}$ & $1301 / 1432$ & $?$ & Târnava & $?$ \\
\hline
\end{tabular}

Fig. 2. Ecclesiastic and administrative-political parish structures north of the Târnava Mare River 